\title{
AZ AKTUÁLIS TELJESÍTMÉNY ÉS A MÖGÖTTE ÁLLÓ TUDÁS DISSZOCIÁCIÓJA: AZ IDÔI TÉNYEZŌK SZEREPÉNEK ÁTTEKINTÉSE A PROCEDURÁLIS TANULÁS PÉLDÁJÁN KERESZTÜL
}

\author{
KISS MARIANN ${ }^{1,3}$ - NÉMETH DEZSÖ ${ }^{2,3,4, *}$ - JANACSEK KAROLINA ${ }^{2,3,5, *}$ \\ ${ }^{1}$ Kognitív Tudományi Tanszék, BME Budapesti Múszaki és Gazdaságtudományi Egyetem, \\ Budapest, Magyarország \\ ${ }^{2}$ Pszichológiai Intézet, ELTE Eötvös Loránd University, Budapest, Magyarország \\ ${ }^{3}$ Emlékezet, Nyelv és Idegtudomány Kutatócsoport, Kognitív Idegtudományi \\ és Pszichológiai Intézet, Budapest, Magyarország \\ ${ }^{4}$ Lyon Neuroscience Research Center (CRNL), Université Claude Bernard Lyon 1, \\ Lyon, France \\ ${ }^{5}$ Gondolkodás és Tanulás Kutatóközpont, Humán Tudományok Intézete, Greenwich-i \\ Egyetem, London, Egyesült Királyság \\ * Szenior szerzók.
}

E-mail: janacsek.karolina@ppk.elte.hu

Benyújtva: 2020. július 7. - Elfogadva: 2020. szeptember 11.

\begin{abstract}
A hétköznapok során gyakran elöfordul, hogy gyengén teljesítünk egy olyan helyzetben, amelyben korábban már bizonyítottuk tudásunkat. A pszichológián belül elméleti és empirikus eredmények is alátámasztják ezt a hétköznapi jelenséget, mely szerint egy adott idôpontban mérhetô teljesítmény (performancia) nem feltétlenül tükrözi húen a mögötte álló tudást (kompetencia). Jelen rövid, célzott összefoglaló tanulmánnyal az a célunk, hogy felhívjuk a figyelmet a performancia-kompetencia disszociációra a procedurális tanulás területét használva példaként. Fontos azonban kiemelni, hogy ez a jelenség más kognitív funkciók esetén is jelen lehet (pl. nyelvi teljesítmény, döntéshozatal, észlelés), ezért tanulmányunk új kutatásokat ösztönözhet számos kognitív funkció esetén. A korábbi empirikus eredmények áttekintésekor külön hangsúlyt fektetünk a tanulás idói faktoraira, amelyek meghatározhatják, hogy disszociáció lép-e fel adott esetben a performancia és kompetencia között vagy nem. Ezután kitérünk azokra az elméleti magyarázatokra is, amelyek az idôi faktorok tanulásra, illetve performancia-kompetencia disszociációra kifejtett hatását próbálják magyarázni. A tanulmány végén kitekintést nyújtunk a disszociáció kutatásmódszertani vonatkozásaira és olyan alkalmazott helyzetekre is, ahol ez a disszociáció jelentösen befolyásolhatja a levont következtetéseket: ilyen például az oktatási-tanulási környezet (készségtanulás, nyelvtanulás), illetve a kognitív tesztek használata a klinikai diagnosztikában.
\end{abstract}

Kulcsszavak: performancia vs. kompetencia; implicit tanulás; probabilisztikus tanulás; válasz-inger intervallum (RSI) 


\section{BEVEZETŐ}

A hétköznapok során gyakran előfordul, hogy gyengén teljesítünk egy olyan helyzetben, amelyben korábban már bizonyítottuk tudásunkat. Például sportolás közben elvétünk egy könnyú helyzetet, nem találjuk a szavakat beszédnél, vagy eltévesztjük az egyébként naponta használt PIN-kódunkat. Ezek mind-mind olyan helyzetek, amelyek jól illusztrálják, hogy az aktuális viselkedéses teljesítményünk ingadozó, és nem fed át a ténylegesen elsajátított tudással (kompetenciával) (Soderstrom és Bjork, 2015). A pszichológiában sem új gondolat, hogy az aktuális teljesítmény (performancia) nem minden helyzetben tükrözi húen az elsajátított tudást (kompetenciát): ez már a nyelv pszicholingvisztikai elméletében (Chomsky, 1965) és a tanulás/memória kísérleti vizsgálatában is régebb óta ismert jelenség (Kantak és Winstein, 2012; Schmidt és Bjork, 1992; Soderstrom és Bjork, 2015). Az aktuális teljesítmény és a hátterében álló tudás disszociációja nagy valószínúséggel más kognitív funkciókra is kiterjedhet, mint például a döntéshozatal, a percepció, nyelvi teljesítmény és a tudatelmélet olyan aspektusaira, amelyek erôsen támaszkodnak tanulási és memóriafolyamatokra (Mutter, Alcorn és Welsh, 2006; Rieskamp és Otto, 2006; Turk-Browne, Scholl, Johnson és Chun, 2010; Ullman, Earle, Walenski és Janacsek, 2020).

Annak ellenére, hogy egy széles körû és fontos jelenségrôl beszélhetünk, az még nagyrészt feltáratlan, hogy milyen körülmények esetében jelenik meg a performancia és a kompetencia ilyen jellegú disszociációja. Ebben a tanulmányban elsôsorban a procedurális tanulás példáján keresztül szeretnénk bemutatni egy ilyen lehetséges körülményt, az adott tanulási helyzet idôi faktoraira fókuszálva. Célunk tehát annak alátámasztása a kurrens szakirodalom bemutatásával, hogy a tanulás idôi faktorai egészen konkrétan az egymást követô ingerek között eltelt idô - okozhat disszociációt az aktuális teljesítmény és a mögöttes tudás (kompetencia) között.

\section{PERFORMANCIA-KOMPETENCIA DISSZOCIÁCIÓ: AZ IDÖI FAKTOROK SZEREPE}

A mindennapok során a környezet mintázatai sokféle eltérô ütemben érnek minket a figyelem akaratlagos irányítása nélkül is, melyek hatással lehetnek a teljesítményünkre. Az így elsajátított motoros, kognitív és szociális készségeink formálnak bennünket, így az oktatásnak és a fejlesztéseknek is a gerincét jelentik. Éppen ezért nem elhanyagolható kérdés, hogy milyen idôi paraméterek mellett érdemes tanulnunk, hogy az a legideálisabb teljesítményt eredményezze, ahogyan az sem mellékes, hogy ez a teljesítmény mennyire tükrözi a ténylegesen elsajátított tudásunkat. Mindez azt is jelenti, hogy a teljesítményünk fokozása és a tanulási folyamataink megértése érdekében is nagy hangsúlyt kell fektetnünk az idôi faktorok vizsgálatára és a teljesítményre, illetôleg a tényleges tudásra kifejtett hatásának megértésére.

Korábbi kutatások alátámasztották, hogy az egymást követô események vagy ingerek között eltelt idô számos kognitív funkció (pl. emlékezet, nyelvelsajátítás, zenei és aritmetikai készségek) esetén befolyásolhatja, hogy agyunk hogyan dolgozza fel, hogyan köti össze ezeket (Davachi és DuBrow, 2015; Destrebecqz és Cleeremans, 
2003; Karlsen, Allen, Baddeley és Hitch, 2010; Schultz, Tremblay és Hollerman, 2003; Wlotko és Federmeier, 2015). Az idôzítés (idôi ritmus) befolyásolja az emlékezést-felejtést is, mivel az egymást követô ingerek között eltelt idô hatással lehet a köztük lévô kapcsolatokról formált emlékek rögzítésére (Barrouillet, Bernardin és Camos, 2004; G. D. Brown, Neath és Chater, 2007; Cornelissen és Greenlee, 2000; Zhang és Luck, 2009). Mindez a neurális válaszok szintjén is megfigyelhetô, az ingerek között eltelt idô függvényében eltérô agyi struktúrák aktiválódása történhet ugyanazon helyzeten belül (pl. Buhusi és Meck, 2005; Foerde és Shohamy, 2011; Schultz és mtsai, 2003). Ugyanakkor az, hogy az idôzítés mennyiben csak az aktuális teljesítményt (performanciát), vagy akár a ténylegesen elsajátított tudást (kompetenciát) is módosítja-e, nem egyértelmú, mivel a legtöbb kutatás nem tett különbséget e kettô között. A következó fejezetekben célzottan azokat a kutatásokat tekintjük át, amelyek a procedurális tanulás területén vizsgálták az ingerek között eltelt idô szerepét, továbbá azt, hogy ez hogyan hat az aktuális teljesítmény és a mögöttes tudás disszociációjára.

\section{PROCEDURÁLIS TANULÁS ÉS MÉRÉSE}

A procedurális tanulás az az alapvetô kognitív funkció, mely lehetôvé teszi számunkra a környezetünkben lévô szekvenciális vagy elófordulási gyakoriság alapján történó mintázatok befogadását, továbbá hozzájárul az automatikus viselkedések elsajátításához, a különbözô motoros, kognitív és szociális készségek és szokások kialakításához (Armstrong, Frost és Christiansen, 2017; Fiser és Aslin, 2002; Romano, Howard és Howard, 2010; Ullman és mtsai, 2020). Procedurális tanulás során a viselkedési repertoár megváltozása általában impliciten, a figyelem akaratlagos irányítása nélkül valósul meg (Cleeremans, Destrebecqz és Boyer, 1998; Reber, 1993). Bizonyos esetekben azonban - például egyszerúbb szabályszerúségek tanulásánál és/vagy hosszabb gyakorlást követốen - expliciten is tudatosíthatjuk az elsajátított szabályszerúségeket (Cleeremans és Jiménez, 2002; Destrebecqz és Cleeremans, 2003; Jacoby, 1991; Reingold és Merikle, 1988). Fontos tehát megjegyezni, hogy az elméletekkel ellentétben a gyakorlatban nincs tisztán implicit vagy tisztán explicit feladat, minden helyzetben elôfordul mindkét tanulási aspektus is, csak eltérô arányban (Destrebecqz és Cleeremans, 2001; Jacoby, 1991).

A procedurális tanulás vizsgálata során a szekvenciális/gyakoriságalapú együtt járások elsajátításának tanulmányozására a leggyakrabban használt mérőeszközök a szekvenciatanulási feladatok (Janacsek és Nemeth, 2012; Nissen és Bullemer, 1987; Ullman és mtsai, 2020), így jelen tanulmányban (a teljesség igénye nélkül) ezekre fókuszálunk elsôsorban.

A Szeriális Reakcióidô Feladat (Serial Reaction Time Task, SRT; Nissen és Bullemer, 1987) során a kísérleti személyek a számítógépen megjelenô ingerekre - pl. négy egymás mellett horizontálisan elhelyezkedô üres körben felvillanó figurákra - a lehetô legpontosabban és leggyorsabban reagálnak a billentyúzet megfeleló gombjainak lenyomásával. A feladat során nem hívják fel arra a kísérleti személyek figyelmét, hogy valójában egy tanulási helyzetben vannak, hiszen az egymást követô ingerek nem véletlenszerúen, hanem egy determinisztikus szekvenciát követve jelennek meg és ismét- 
lôdnek a feladat során (pl. 243123142134, ahol a számok a monitoron lévô négy kör valamelyikét jelentik). Adott idô elteltével tesztelik a reakcióidô és a pontosság mérésének segítségével a tanulás eredményességét: a gyakorlás során a kísérleti személyek pontossága nô, reakcióideje pedig jelentôsen lecsökken a már ismert szekvencia bemutatása esetében, szemben egy ettôl eltérô, korábban nem gyakorolt szekvenciával (pl. 342131243214), azaz kimutatható egy tanulási hatás (Nissen és Bullemer, 1987) (lásd 1. ábra, bal oldali oszlop).

Az Alternáló Szeriális Reakcióidô Feladat (Alternating Serial Reaction Time, ASRT; Howard és Howard, 1997; Kóbor, Janacsek, Takács és Nemeth, 2017; Nemeth és mtsai, 2010) tulajdonképpen az SRT-nek egy olyan módosított változata, ahol az ismétlôdó szekvenciaelemek random elemekkel alternálódva jelennek meg (pl. 2r4r3r1 $r$, ahol a számok a monitoron lévô négy kör valamelyikét jelentik, míg az $r$ a random elemeket, amelyek véletlenszerúen választódnak ki a négy lehetséges pozíció közül) (lásd 1. ábra,

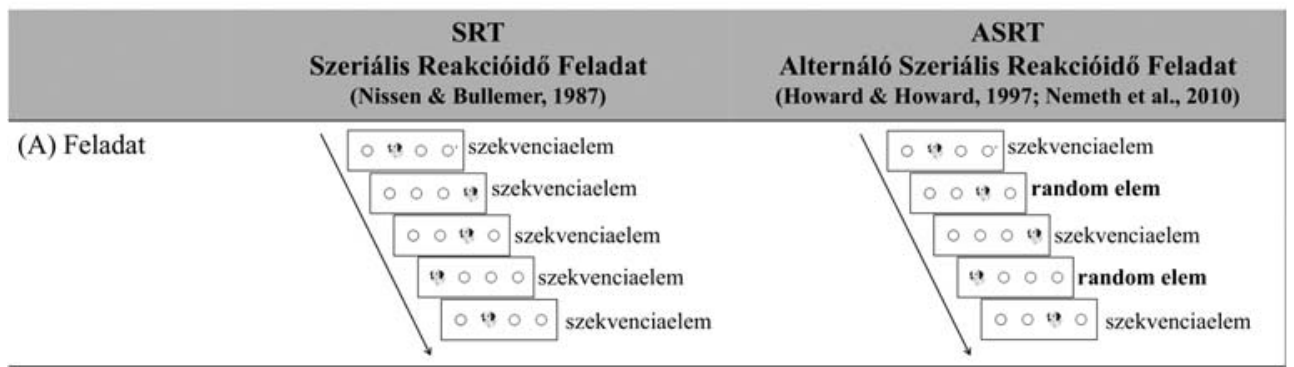

(B) Szekvencia Determinisztikus szekvencia: $\begin{array}{llllllllllll}4 & 3 & 1 & 2 & 4 & 3 & 1\end{array}$

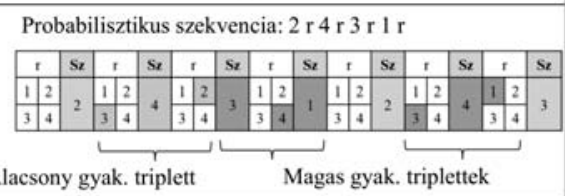

(C) Teljesítménymérés

\begin{tabular}{|c|c|c|c|c|c|c|c|}
\hline Sx & Sx & Sz & Sz & Sz & Sz & Sz & Sz \\
\hline 2 & 4 & 3 & 1 & 2 & 4 & 3 & 1 \\
\hline
\end{tabular}

Alacsony gyak. triplett Magas gyak. triplettek
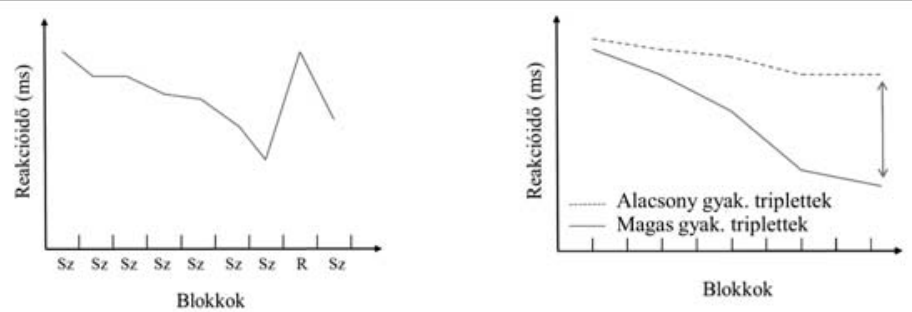

1. ábra. A procedurális tanulás mérésére gyakran használt két feladat illusztrációja

Megjegyzés: (A) Mind a Szeriális Reakcióidô Feladat (SRT), mind az Alternáló Szeriális Reakcióidô Feladat (ASRT) esetében a vizsgálati személyek a megfelelố válaszgombok megnyomásával válaszolnak a képernyôn bemutatott vizuális ingerekre. A vizsgálati személyek általában nem kapnak tájékoztatást arról, hogy az ingerek megjelenési sorrendje nem véletlen, hanem egy előre meghatározott szabályszerúséget követ. (B) A legfő̉bb különbség a két feladat között: Az SRT-ben a szekvencia általában determinisztikus, az ingerek egy előre meghatározott sorrendben követik egymást. Az ASRT-ben ezzel szemben a szekvencia probabilisztikus, az elôre meghatározott sorrendben érkezô ingerek közé random elemek ékelôdnek. (C) A két feladat esetében a teljesítménymérés is eltér. A determinisztikus SRT feladatokban a tanulási teljesítményt általában az elöre meghatározott szekvenciát (Sz) tartalmazó blokkokban adott válaszok reakcióidejének és egy ettôl eltérô, korábban nem gyakorolt szekvenciát vagy random sorrendú elemeket (R) tartalmazó blokkban adott válaszok reakcióidejének a különbsége adja. A tanulási teljesítmény számszerúsítésére általában a tanulás vége felé kerül sor. Az ASRT feladatban a tanulási teljesítmény a tanulás teljes idôtartama alatt mérhetô, méghozzá a probabilisztikus struktúrából adódóan bejósolhatóbb (ún. magas gyakoriságú triplettek) és kevésbé bejósolható (ún. alacsony gyakoriságú triplettek) ingerek reakcióidő-különbségeként. 
jobb oldali oszlop). Mivel egyfelôl itt sem tájékoztatják a kísérleti személyeket az ismétlôdésekrôl, másfelôl a klasszikus SRT-hez képest itt valamivel komplexebb, probabilisztikus szekvenciák szerepelnek, a tudás az esetek nagyobb százalékában marad implicit. Az ASRT feladatstruktúrája lehetôvé teszi, hogy a tanulás során az ún. általános készségtanulást elkülönítsük a tényleges probabilisztikus struktúra elsajátításától. Az eloobbi egy általános gyorsulásként ragadható meg a gyakorlás során, ami ugyanúgy megjelenik az ismétlôdô szekvencia-, illetve a random elemeken is. Ezzel szemben az utóbbi általában abban nyilvánul meg, hogy a probabilisztikus struktúra következtében bejósolhatóbb ingerekre a vizsgálati személyek a gyakorlás előrehaladtával gyorsabban és pontosan válaszolnak, szemben a kevésbé bejósolható ingerekkel (Nemeth és mtsai, 2013). Az ASRT feladat tehát lehetôvé teszi, hogy a feladatban jelen levő (probabilisztikus) struktúra tanulásának idóbeli lefolyását is nyomon követhessük, megbízhatóbb mérési eredményeket adva mind a pontosság, mind a reakcióidó tekintetében, szemben a determinisztikus szekvenciákat használó SRT-vel (Stark-Inbar, Raza, Taylor és Ivry, 2016; West, Vadillo, Shanks és Hulme, 2017).

\section{AZ IDŐZÍTÉS SZEREPE A PROCEDURÁLIS TANULÁSBAN}

Az egyik alapvetô tényezô, amely befolyásolhatja a teljesítményt és a tanulás folyamatát is, az az egymást követô ingerek idôzítése, vagyis az, hogy a környezetünkben milyen tempóban, milyen ritmusban érnek minket a különbözó ingerek. Több kutatás is vizsgálta az idôzítés szerepét a procedurális tanulásban (pl. Arciuli és Simpson, 2011; Bogaerts, Siegelman és Frost, 2016; Destrebecqz és Cleeremans, 2003; Emberson, Conway és Christiansen, 2011; Frensch és Miner, 1994; Soetens, Melis és Notebaert, 2004; Willingham, Greenberg és Thomas, 1997). Bár a kutatások többsége egyetért abban, hogy a gyorsabb ütemú idôzítés általában elônyösebb a tanulás szempontjából, mint a lassabb ütemú, azt nem tisztázzák ezek a kutatások, hogy ez elsôsorban a szabályszerúségek elsajátítására (a kompetenciára) vagy az adott idôpontban mért teljesítményre vonatkozik-e, mely utóbbi eltérhet a ténylegesen elsajátított tudástól.

\section{Az idốzités manipulálására alkalmas mutatók}

Mindkét fent említett lehetôség esetén az idôzítés megváltoztathatja az ingerekre adott idegrendszeri válaszokat, átváltva egyik neurális hálózatról egy másikra (pl. Buhusi és Meck, 2005; Foerde és Shohamy, 2011; Schultz és mtsai, 2003). Módszertanilag a kutatások során az adott kognitív funkció vagy mentális reprezentáció mérésekor a célnak megfelelố optimális beállítást lenne szükségszerú meghatározni, ideértve a viselkedéses és az idegrendszeri méréseket is. Jelen probléma a kognitív vizsgálatoknak széles körét érintheti, függetlenül a használt idôzítési mutatótól, pl. válasz-inger intervallum (response-to-stimulus interval, RSI), próbák közötti idői intervallum (inter-trial-interval, ITI) vagy ingerkezdetek közötti aszinkronitás (stimulus-onset asynchrony, SOA) (Emberson és mtsai, 2011; Foster és Giovanello, 2017; Mechelli, Friston és Price, 2000; Shin és Ivry, 2002). A továbbiakban a jelen összefoglaló tanulmány a válasz-inger intervallumot manipuláló kísérletekre fókuszál, ugyanis ez kapott viszonylag nagyobb figyelmet a procedurális tanulás vizsgálatában. 


\section{A válasz-inger intervallum hosszának hatása a procedurális tanulásra}

Az ingerbemutatás idôzítését leggyakrabban a válasz-inger intervallum módosításával, tehát adott válasz és az azt követô inger között eltelt idô hosszának megváltoztatásával manipulálták a procedurális tanulással foglalkozó kutatások (Willingham és mtsai, 1997). A legtöbben azt találták, hogy a rövidebb és/vagy kongruensebb válasz-inger intervallumok jobb tanulási teljesítményt eredményeztek, föleg ha a teljesítményt a reakcióidó mutatókkal mérték (Destrebecqz és Cleeremans, 2003; Dominey, 1998; Frensch és Miner, 1994; Howard, Howard, Dennis és Yankovich, 2007; Kiss, Nemeth és Janacsek, 2019; Nissen és Bullemer, 1987; Soetens és mtsai, 2004; Stadler, 1995). Mások ezzel épp ellentétes mintázatot tártak fel: a válasz-inger intervallum hosszának növelése eredményezhet teljesítményjavulást, elsôsorban akkor, ha a teljesítményt pontosság- és önbevallásos mutatókkal definiálták (Arciuli és Simpson, 2011; Emberson és mtsai, 2011). A vegyes eredmények részben magyarázhatók a feladatban használt teljesítménymutatók eltérésével (pl. reakcióidố vs. pontosság), részben viszont a szabályszerúségek tudatosíthatóságának eltérô szintje (pl. a szekvenciáról való elsajátított tudás mennyire vált explicitté a gyakorlás során, vagy mennyire maradt végig implicit) is felelôs lehet az egymásnak ellentmondó következtetésekért (Destrebecqz és Cleeremans, 2003; Frensch és Miner, 1994). Például kimutatták, hogy SRT feladatban a determinisztikus szekvenciáról való tudás a válasz-inger intervallum növelésével (pl. 0, 250 vs. $1500 \mathrm{~ms}$ ) valóban egyre explicitebbé, akaratlagosan hozzáférhetôbbé válik (Destrebecqz és Cleeremans, 2003), ezzel szemben az ASRT feladatban, vagyis probabilisztikus szekvencia elsajátítása során nem figyelhetó meg ilyen jellegú kapcsolat (pl. 120 vs. 850 ms-os válasz-inger intervallum mellett is implicit maradt a tudás) (Kiss és mtsai, 2019).

A válasz-inger intervallum hossza mellett fontos tényezô a válasz-inger intervallum kongruenciája is, mind a tanulási fázison belül, mind pedig a tanulási és késôbbi, esetleges tesztelési fázisok között is. A tanulási fázison belül például kimutatták, hogy a válasz-inger intervallum módosítása (pl. ha a feladaton belül bármilyen értéket felvehet 400 és 2000 ms között, akár random módon) gyengébb teljesítményt eredményezhet SRT feladatban (Dominey, 1998; Stadler, 1995). Howard és munkatársai (2007) is hasonló eredményre jutottak: ASRT feladatban, tehát probabilisztikus szekvenciatanulás esetén is a teljesítmény leromlását okozta a hosszabb és variábilisabb válasz-inger intervallum, ugyanakkor felvetették, hogy mindez azzal hozható összefüggésbe, hogy a kontextus meggátolja a tényleges kompetencia kifejezódését. Emellett a tanulási és tesztelési fázis közötti idôzítésmódosítás is hatással lehet a teljesítményre, ugyanakkor nem mindegy, hogy a válasz-inger intervallumnak milyen irányú módosításáról van szó (Willingham és mtsai, 1997). Elképzelhetô, hogy a tanulási fázis során lévô válasz-inger intervallum hossza és a tesztelés során a módosítás iránya egymással interakcióban hat a teljesítményre: 1 . a tanulás idôzítésétôl függetlenül a legjobb teljesítményt akkor kapjuk, ha nem módosítunk a válasz-inger intervallumon a tesztelés során ehhez képest, 2. ugyanakkor az idôzítés módosítása akkor hat a leginkább (negatívan) a teljesítményre, ha a tanuláshoz képest a teszteléskor megnöveljük a válasz-inger intervallum hosszát (pl. 120 ms-ról 850 ms-ra) (Kiss és mtsai, 2019). Fontos azonban hangsúlyozni, hogy kevés kutatás kivételével (Howard és mtsai, 2007; Kiss és mtsai, 2019; Willingham 
és mtsai, 1997), a legtöbb vizsgálat nem tesztelte, hogy a válasz-inger intervallum hoszsza/kongruenciája elsôsorban a szabályszerúségek elsajátítására (a kompetenciára) vagy az adott idôpontban mért teljesítményre hatott-e, mely utóbbi disszociálódhat a ténylegesen elsajátított tudástól. A továbbiakban két olyan kutatást tárgyalunk részletesebben, melyek e lehetséges disszociáció feltárására fókuszáltak.

\section{A válasz-inger intervallum hatása a kompetencia-performancia disszociációra}

A kompetencia és performancia szétválasztásának tesztelésére alkalmas lehet egy transzferkondíció alkalmazása, amely során adott idôzítés mellett tanult személyeket késôbb más, ettôl eltérô idôzítéssel tesztelünk ugyanazon a feladaton (Willingham és mtsai, 1997). Például ha egy feladatot lassabb tempóval (hosszabb válasz-inger intervallummal) tanultunk, és utána jobban teljesítünk, amikor ugyanazt a feladatot az eredetihez képest gyorsabb tempóban (rövidebb válasz-inger intervallummal) végezzük el, ez arra utal, hogy az eredeti kondícióban az aktuális teljesítmény nem reflektált pontosan a ténylegesen elsajátított tudásra, hiszen a megváltozott másik körülményben jobb teljesítményt is képesek voltunk produkálni (Kiss és mtsai, 2019; Willingham et al., 1997).

Willingham és munkatársai (1997) determinisztikus SRT-t használó vizsgálatukban épp ilyen eredményt kaptak: a hosszabb (1500 vagy 2000 ms) válasz-inger intervallummal tanult személyek is jobban teljesítettek, amikor a rövidebb (500 ms) válasz-inger intervallummal tesztelték a tudásukat. Ezzel összhangban, amikor a rövidebb válasz-inger intervallummal tanult csoportot a hosszabb válasz-inger intervallummal tesztelték, teljesítményük leromlott. Ezek az eredmények azt jelzik, hogy a hosszabb idôi paraméter maszkolta a személyek ténylegesen elsajátított tudását, hiszen azt jobban ki tudták fejezni a feladat rövidebb válasz-inger intervallum változatában. Tudomásunk szerint ez volt az elsố olyan kutatás, amely a procedurális tanuláson belül felhívta a figyelmet arra, hogy az idôzítés (pontosabban az egymás követố ingerek között eltelt idô) befolyásolja azt, hogy az aktuálisan mért teljesítmény húen tükrözi-e a ténylegesen elsajátított tudást egy adott helyzetben.

Egy újabb kutatásban Kiss és munkatársai (2019) a probabilisztikus szekvenciatanulási ASRT feladaton tesztelték a vizsgálati személyek teljesítményét hasonló transzferkondíció segítségével. A vizsgálati személyek 120 vagy 850 ms-os válasz-inger intervallummal végezték el a feladatot a tanulási szakaszban, majd 24 óra múlva mindkét csoport teljesítménye tesztelésre került mindkét idôzítéssel. A 24 órás késleltetés célja az volt, hogy a tanulási szakaszban elsajátított tudás megfelelôen megszilárduljon (vagyis konszolidálódjon) a tesztelés elôtt (Kóbor és mtsai, 2017; Nemeth és Janacsek, 2011). Ez biztosította, hogy a feladat idôzítésének megváltoztatása nem a további tanulásra hat, és így tisztábban mérhetô vele a tudás vs. teljesítmény esetleges disszociációja. Az eredmények felfedték, hogy mindkét csoport elsajátította a szekvenciát, és annak ellenére, hogy az elsố napon a lassabb ütemmel tanult csoport gyengébben teljesített, ez nem tükrözte húen a ténylegesen elsajátított tudásukat: Amikor ez a csoport gyorsabb ütemben végezhette el a feladatot a tesztelési fázisban, ugyanolyan jó teljesítményt mutattak, mint a gyorsabb ütemben tanult csoport - elsôsorban akkor, amikor 
a teljesítményük reakcióidôn keresztül volt mérve. Azok, akik gyors ütemben tanultak, gyengébben teljesítettek akkor, amikor lassú ütemben tesztelték ôket, mind reakcióidô, mind pontosság mutatókkal mérve. Ezek az eredmények arra utalnak, hogy a lassabb idôi paraméterek nem tették lehetôvé, hogy a vizsgálati személyek által elsajátított tudás megfelelốen kifejezôdjön. A kutatás azt is tesztelte, hogy az elsajátított tudás milyensége (explicit vagy implicit) különbözik-e a különbözô idôzítéssel tanult csoportoknál, és arra jutottak, hogy az elsajátított tudás implicit maradt mindkét csoportban, tehát az idôzítés a tanulás ezen aspektusára nem hatott (Kiss és mtsai, 2019).

\section{A kompetencia-performancia megkülönböztetés szükségessége}

Ahogyan azt már korábban is hangsúlyoztuk, a kompetencia-performancia disszociáció jelensége - vagyis hogy az aktuális teljesítmény (performancia) nem minden helyzetben tükrözi húen a mögöttes elsajátított tudást (kompetenciát) - a pszicholingvisztikában elméleti szinten ismert (Chomsky, 1965), a tanulás-memória területén pedig több kutatás eredménye is alátámasztja ennek a jelenségnek a létezését (Kantak és Winstein, 2012; Schmidt és Bjork, 1992; Soderstrom és Bjork, 2015). Ennek ellenére az, hogy pontosan milyen körülmények között jöhet létre ez a disszociáció, már kevésbé ismert. Jelen tanulmánnyal ezért azt kívántuk bemutatni, hogy az idózítés - a tanulmányban használt példák esetében konkrétan az egymást követô ingerek között eltelt idô - lehet az egyik disszociációhoz vezetô körülmény. Ez pedig pl. a válasz-inger intervallum szisztematikus manipulálásával tesztelhetô, ahogy azt a fentebb bemutatott kutatások is tették.

A lehetséges kompetencia-performancia disszociációtól függetlenül számos kutatás kimutatta, hogy az egymást követô ingerek között eltelt idô befolyásolja, hogy hogyan dolgozzuk fel és kötjük össze ezeket az ingereket (Destrebecqz és Cleeremans, 2003; Staresina és Davachi, 2009; Wlotko és Federmeier, 2015). Ezen kutatások alapján tehát várható, hogy a feladat idôi paraméterei az elsajátított tudásra és annak a teljesítményben való kifejezôdésére is hatással lehetnek. A következókben három olyan lehetséges elméleti megközelítést vázolunk fel, amelyek az időzítés szerepét magyarázhatják.

Ezek közül két megközelítés az idôzítés kompetenciára kifejtett hatását hangsúlyozza ki. Az elsố megközelítés szerint a feladat idôi paraméterei azt befolyásolhatják, hogy milyen tudást szerzünk meg az adott feladatban: pontosabban, az ingerek között megnövelt intervallum miatt több idô állhat rendelkezésre az ingerek tudatos (explicit), elaboráltabb feldolgozásához, ami nagyobb tudáshoz (és ezzel együtt jobb teljesítményhez) vezethet (Cleeremans és Jiménez, 2002; Conway, 2020; Destrebecqz és Cleeremans, 2003; Reber, 1993). Az empirikus eredmények egy része, amelyek az idôzítés hatását vizsgálták a tanulásra vagy a kompetencia-performancia disszociációra, azonban nem támasztja alá ezt az érvelést (Howard és mtsai, 2007; Kiss és mtsai, 2019).

A második elméleti megközelítés szerint az egymást követô ingerek között eltelt idô befolyásolhatja, hogy agyunk milyen kapcsolatot talál köztük, például hogy összekapcsolja-e ôket (Davachi és DuBrow, 2015; Karlsen és mtsai, 2010). Minél több idô telik el az elôzố ingert követôen, annál valószínúbb, hogy az adott ingerrôl kialakított emléknyom elhalványul (összhangban a felejtés idóbeli hanyatlás elméleteivel) (Altmann, 
2009; Barrouillet, De Paepe és Langerock, 2012; J. Brown, 1958; Mercer és McKeown, 2014; Ricker és Cowan, 2010). Így a megnövelt idôintervallum csökkenti annak a valószínúségét, hogy az egymást követô ingerek együtt reprezentálódjanak és összekapcsolódjanak egy helyi rövidtávú memóriában (Janacsek és Nemeth, 2013, 2015), megakadályozva a közöttük levô kapcsolat elsajátítását (Destrebecqz és Cleeremans, 2003; Dominey, 1998; Frensch és Miner, 1994; Soetens és mtsai, 2004; Stadler, 1995). A procedurális tanulás fent bemutatott példáiban azonban ez a megközelítés sem magyarázza az eredményeket, hiszen pl. mind Willingham és munkatársai (1997), mind pedig Kiss és munkatársai (2019) azt mutatták ki, hogy a gyorsabb tempójú tesztelés során jobb teljesítményt mutattak azok a vizsgálati személyek, akik egyébként lassú tempó mellett tanultak. Ettôl függetlenül elképzelhetô, hogy más feladatokban vagy helyzetekben az idôzítés a ténylegesen elsajátított tudásra is hatással lehet.

A harmadik megközelítés a kompetencia és performancia disszociációját hivatott magyarázni: eszerint, ha az egymást követô ingerek elég közel vannak egymáshoz idôben, akkor az elôzó inger reprezentációja még aktív lehet abban az idôi ablakban, amikor a kísérleti személy válaszol a következô ingerre is, ezáltal facilitálva a választ (Burle, Van den Wildenberg és Ridderinkhof, 2005; Scharlau, 2007; Wlotko és Federmeier, 2015). Fordítva, ha túl sok idô telik el az egymást követô ingerek között, akkor a korábbi inger aktivációja már lecseng, amikor az aktuális ingerre kell válaszolni, így ha annak válaszfacilitáció hatása lett volna, akkor az már nem lesz tapasztalható. Kiss és munkatársai (2019) ezt a megközelítést használták az eredményeik magyarázatára. Azt feltételezték, hogy a nagyobb jóslóerôvel rendelkezô szekvenciarészek esetében nagyobb az egymást követô ingerek válaszfacilitációja, mint a kevésbé bejósolhatók esetén. A gyorsabb ütem pedig lehetôvé teszi, hogy ez a válaszfacilitáció tisztábban kifejezôdjön, ezáltal jobb teljesítményt eredményezve, mint a feladat lassabb tempójú változatában.

\section{IMPLIKÁCIÓK ÉS ÖSSZEFOGLALÁS}

Röviden, indokolt a feltételezés, mely szerint az egymást követô ingerek közt eltelt idô befolyásolhatja a kompetencia és performancia disszociációját, amely azonban nem független mást tényezóktôl sem: szerepe lehet a feladat típusának (pl. vizuális vagy auditoros, verbális vagy nonverbális) és komplexitásának (összetettségének, nehézségének) is. Az egymás követô ingerek között eltelt idô szerepét hangsúlyozzák a (leginkább a rövidtávú és munkamemórián belüli) felejtéselméletek is, és bár elég nagy szórás van a konkrét idôi intervallumok meghatározásában, ezek az eredmények együttesen rávilágítanak arra, hogy a tanuláson és a memórián belül is alapvetô szerepe van az ingerek között eltelt idônek (Barrouillet és mtsai, 2004; G. D. Brown és mtsai, 2007; Cornelissen és Greenlee, 2000; Horoufchin, Philipp és Koch, 2011; Mercer és McKeown, 2014; Oberauer, Farrell, Jarrold és Lewandowsky, 2016; Schweickert és Boruff, 1986; Zhang és Luck, 2009).

A fentebb bemutatott irodalmakkal azt szerettük volna hangsúlyozni, hogy az egymást követó ingerek között eltelt idô nem csak a kompetenciát (az elsajátított tudást vagy emléknyomokat), de ennek a kompetenciának az aktuális teljesítményben mér- 
hetô kifejezôdését is befolyásolhatja. Rövid összefoglaló tanulmányunkkal szeretnénk felhívni arra a figyelmet, hogy a késóbbi kutatások során nagyobb hangsúlyt kellene fektetni erre a kérdésre, nem csak a procedurális tanulás területén: fontos lenne szisztematikusan tesztelni több kognitív funkción belül is ezt a disszociációt, illetôleg azt, hogy a különbözó idői faktorok hogyan hatnak rá.

Emellett szeretnénk felhívni a figyelmet arra is, hogy a további kutatások során olyan kísérleti elrendezéseket lenne érdemes létrehozni, amelyek képesek feltárni az aktuális teljesítmény és a mögöttes tudás közti eltéréseket, ezáltal elkerülhetôvé téve a performanciából történô esetlegesen téves következtetéseket. Az egyik fontos tényezô, amit nem árt figyelembe venni, az a teljesítmény többszörös tesztelése eltéró kontextushelyzetekben (pl. eltérô idôi faktorok, eltérô szóbeli instrukciók) (Vékony és mtsai, 2019). Az ilyen jellegú kísérleti elrendezések lehetôvé tehetik a kognitív funkciók és mentális reprezentációk viselkedéses (és neurális) aspektusainak pontosabb mérését. A viselkedéses adatok esetében érdemes többféle mérésen alapuló mutatókat (pl. pontosság és reakcióidô) is alkalmazni, hiszen ezek alkalomadtán legalább részben eltéró kognitív funkciókra reflektálhatnak (Burgess, Gilbert és Dumontheil, 2007; Janacsek, Fiser és Nemeth, 2012; Prinzmetal, McCool és Park, 2005). Ezen szempontok betartásával a késóbbi kutatások pontosabban feltárhatják, hogy mit mutathat az aktuális teljesítmény, és ez mennyire válik el a kompetenciától.

Nem utolsósorban az alkalmazott területeken, például az oktatásban, a nyelvtanulásban, a sportokban, a klinikai diagnosztikában és a rehabilitációban is jelentôs vonatkozásai lehetnek a kompetencia-performancia lehetséges disszociációjának. Például, készségtanulási helyzetben a tanuló jobb teljesítményt mutathat, ha gyorsabb ütemben kell teljesítenie a feladatot. A klinikum területén elófordulhat, hogy adott betegpopuláció az egészséges kontrollokhoz képest azért teljesít gyengébben egy önütemezett feladatban, mert a saját tempójuk általánosan lelassult, ami elfedi a tényleges kompetenciájukat. Fontos hangsúlyoznunk, hogy az idózítés csak egy példa, amely módosíthatja a kontextushelyzetet: készségtanulás közben, és a klinikumban is elôfordulhat, hogy valamely nem figyelt körülmény miatt (legyen az egy helytelenül megfogalmazott instrukció, a megszokottól eltérô környezet, vagy a vizsgált személy hangulati és/vagy éberségi állapota, esetlegesen fizikai jellemzôi) az aktuális teljesítmény disszociálódhat a tényleges kompetenciától, ezzel befolyásolva az általunk választott mérốeszköz validitását. Érdemes tehát többek között az idôi faktorokat is figyelembe venni ezekben a helyzetekben, például eltérô kontextushelyzetben történô többszörös tesztelés révén.

Rövid összefoglaló tanulmányunk tehát arra hívja fel a figyelmet - a procedurális tanulás példáján keresztül -, hogy a performancia nem minden helyzetben tükrözi hûen a mögötte álló kompetenciát, és az idôzítés az egyik lehetséges tényezô, amely ezt befolyásolhatja. A további elméleti és gyakorlati kutatásoknak fontos lenne figyelembe vennie és tesztelnie a kompetencia és performancia lehetséges disszociációját és annak meghatározó tényezóit, nem csupán a tanulás és a memória, de más kognitív funkciók, például a döntéshozatal, a percepció és a nyelv különbözô aspektusaiban is. 


\section{KÖSZÖNETNYILVÁNÍTÁS}

A kutatást a Nemzeti Agykutatás Program (projekt 2017-1.2.1-NKP-2017-00002), a Nemzeti Kutatási, Fejlesztési és Innovációs Hivatal (NKFIH-OTKA K 128016 [ND], NKFIH-OTKA PD 124148 [JK]) és a Bolyai János Kutatói Ösztöndíj (JK) támogatta.

\section{IRODALOM}

Altmann, E. M. (2009). Evidence for temporal decay in short-term episodic memory. Trends in Cognitive Sciences, 13(7), 279.

Arciuli, J., \& Simpson, I. C. (2011). Statistical learning in typically developing children: the role of age and speed of stimulus presentation. Developmental Science, 14(3), 464-473.

Armstrong, B. C., Frost, R., \& Christiansen, M. H. (2017). The long road of statistical learning research: past, present and future. Philosophical Transactions of The Royal Society B Biological Sciences, 372(1711), 20160047.

Barrouillet, P., Bernardin, S., \& Camos, V. (2004). Time constraints and resource sharing in adults' working memory spans. Journal of Experimental Psychology: General, 133(1), 83.

Barrouillet, P., De Paepe, A., \& Langerock, N. (2012). Time causes forgetting from working memory. Psychonomic Bulletin E Review, 19(1), 87-92.

Bogaerts, L., Siegelman, N., \& Frost, R. (2016). Splitting the variance of statistical learning performance: A parametric investigation of exposure duration and transitional probabilities. Psychonomic Bulletin \& Review, 23(4), 1250-1256.

Brown, G. D., Neath, I., \& Chater, N. (2007). A temporal ratio model of memory. Psychological Review, 114(3), 539.

Brown, J. (1958). Some tests of the decay theory of immediate memory. Quarterly Journal of Experimental Psychology, 10(1), 12-21.

Buhusi, C. V., \& Meck, W. H. (2005). What makes us tick? Functional and neural mechanisms of interval timing. Nature Reviews Neuroscience, 6(10), 755.

Burgess, P. W., Gilbert, S. J., \& Dumontheil, I. (2007). Function and localization within rostral prefrontal cortex (area 10). Philosophical Transactions of the Royal Society B: Biological Sciences, 362(1481), 887-899.

Burle, B., Van den Wildenberg, W., \& Ridderinkhof, K. R. (2005). Dynamics of facilitation and interference in cue-priming and Simon tasks. European Journal of Cognitive Psychology, 17(5), 619-641.

Chomsky, N. (1965). Aspects of the theory of syntax. Cambridge, Massachusetts: MIT Press.

Cleeremans, A., Destrebecqz, A., \& Boyer, M. (1998). Implicit learning: news from the front. Trends in Cognitive Sciences, 2(10), 406-416.

Cleeremans, A., \& Jiménez, L. (2002). Implicit learning and consciousness: A graded, dynamic perspective. In French, R. M., \& Cleeremans, A. (Eds), Implicit Learning and Consciousness: An Empirical. Psychology Press. 1-40.

Conway, C. M. (2020). How does the brain learn environmental structure? Ten core principles for understanding the neurocognitive mechanisms of statistical learning. Neuroscience and Biobehavioral Reviews, 112, 279-299.

Cornelissen, F. W., \& Greenlee, M. W. (2000). Visual memory for random block patterns defined by luminance and color contrast. Vision Research, 40(3), 287-299.

Davachi, L., \& DuBrow, S. (2015). How the hippocampus preserves order: the role of prediction and context. Trends Cogn Sci, 19(2), 92-99. 
Destrebecqz, A., \& Cleeremans, A. (2001). Can sequence learning be implicit? New evidence with the process dissociation procedure. Psychonomic Bulletin \& Review, 8(2), 343-350.

Destrebecqz, A., \& Cleeremans, A. (2003). Temporal effects in sequence learning. Advances in Consciousness Research, 48, 181-214.

Dominey, P. F. (1998). Influences of temporal organization on sequence learning and transfer: Comments on Stadler (1995) and Curran and Keele (1993). Journal of Experimental Psychology: Learning, Memory, and Cognition, 24(1), 234.

Emberson, L. L., Conway, C. M., \& Christiansen, M. H. (2011). Timing is everything: Changes in presentation rate have opposite effects on auditory and visual implicit statistical learning. The Quarterly Journal of Experimental Psychology, 64(5), 1021-1040.

Fiser, J., \& Aslin, R. N. (2002). Statistical learning of higher-order temporal structure from visual shape sequences. Journal of Experimental Psychology. Learning, Memory, and Cognition, $28(3), 458-467$.

Foerde, K., \& Shohamy, D. (2011). Feedback timing modulates brain systems for learning in humans. Journal of Neuroscience, 31(37), 13157-13167.

Foster, C. M., \& Giovanello, K. S. (2017). The effect of presentation rate on implicit sequence learning in aging. Memory, 25(2), 187-200.

Frensch, P. A., \& Miner, C. S. (1994). Effects of presentation rate and individual differences in short-term memory capacity on an indirect measure of serial learning. Memory and Cognition, 22(1), 95-110.

Horoufchin, H., Philipp, A. M., \& Koch, I. (2011). The dissipating task-repetition benefit in cued task switching: Task-set decay or temporal distinctiveness? Journal of Experimental Psychology: Human Perception and Performance, 37(2), 455.

Howard, J. H., Jr., \& Howard, D. V. (1997). Age differences in implicit learning of higher-order dependencies in serial patterns. Psychology and Aging, 12(4), 634-656. doi: 10.1037/0882-7974.12.4.634

Howard, J. H., Jr., Howard, D. V., Dennis, N. A., \& Yankovich, H. (2007). Event timing and age deficits in higher-order sequence learning. Aging, Neuropsychology, and Cognition, 14, $647-668$.

Jacoby, L. L. (1991). A process dissociation framework: Separating automatic from intentional uses of memory. Journal of Memory and Language, 30, 513-541.

Janacsek, K., Fiser, J., \& Nemeth, D. (2012). The best time to acquire new skills: age-related differences in implicit sequence learning across the human lifespan. Developmental Science, 15(4), 496-505. doi: 10.1111/j.1467-7687.2012.01150

Janacsek, K., \& Nemeth, D. (2012). Predicting the future: From implicit learning to consolidation. International Journal of Psychophysiology, 83(2), 213-221.

Janacsek, K., \& Nemeth, D. (2013). Implicit sequence learning and working memory: correlated or complicated? Cortex, 49(8), 2001-2006.

Janacsek, K., \& Nemeth, D. (2015). The puzzle is complicated: When should working memory be related to implicit sequence learning, and when should it not? (Response to Martini és mtsai). Cortex, 64, 411-412.

Kantak, S. S., \& Winstein, C. J. (2012). Learning-performance distinction and memory processes for motor skills: A focused review and perspective. Behavioural Brain Research, 228(1), 219-231.

Karlsen, P. J., Allen, R. J., Baddeley, A. D., \& Hitch, G. J. (2010). Binding across space and time in visual working memory. Memory and Cognition, 38(3), 292-303.

Kiss, M., Nemeth, D., \& Janacsek, K. (2019). Stimulus presentation rates affect performance but not the acquired knowledge—Evidence from procedural learning. bioRxiv, 650598. 
Kóbor, A., Janacsek, K., Takács, Á., \& Nemeth, D. (2017). Statistical learning leads to persistent memory: Evidence for one-year consolidation. Scientific Reports, 7(1), 760. doi: 10.1038/ s41598-017-00807-3

Mechelli, A., Friston, K. J., \& Price, C. J. (2000). The effects of presentation rate during word and pseudoword reading: a comparison of PET and fMRI. Journal of Cognitive Neuroscience, 12(Supplement 2), 145-156.

Mercer, T., \& McKeown, D. (2014). Decay uncovered in nonverbal short-term memory. Psychonomic Bulletin \& Review, 21(1), 128-135.

Mutter, B., Alcorn, M. B., \& Welsh, M. (2006). Theory of mind and executive function: Workingmemory capacity and inhibitory control as predictors of false-belief task performance. Perceptual and Motor Skills, 102(3), 819-835.

Nemeth, D., \& Janacsek, K. (2011). The dynamics of implicit skill consolidation in young and elderly adults. Journal of Gerontology Psychological Science, 66(1), 15-22.

Nemeth, D., Janacsek, K., Király, K., Londe, Z., Németh, K., Fazekas, K., és mtsai (2013). Probabilistic sequence learning in mild cognitive impairment. Frontiers in Human Neuroscience, 7, 318. doi: 10.3389/fnhum.2013.00318

Nemeth, D., Janacsek, K., Londe, Z., Ullman, M. T., Howard, D. V., \& Howard, J. H., Jr. (2010). Sleep has no critical role in implicit motor sequence learning in young and old adults. $E x$ perimental Brain Research, 201(2), 351-358. doi: 10.1007/s00221-009-2024-x

Nissen, M. J., \& Bullemer, P. (1987). Attentional requirements of learning: Evidence from performance measures. Cognitive Psychology, 19, 1-32.

Oberauer, K., Farrell, S., Jarrold, C., \& Lewandowsky, S. (2016). What limits working memory capacity? Psychological Bulletin, 142(7), 758.

Prinzmetal, W., McCool, C., \& Park, S. (2005). Attention: Reaction time and accuracy reveal different mechanisms. Journal of Experimental Psychology: General, 134(1), 73-92. doi: 10.1037/0096-3445.134.1.73

Reber, A. S. (1993). Implicit learning and tacit knowledge: An essay on the cognitive unconscious. Vol. 19. New York: Oxford University Press.

Reingold, E. M., \& Merikle, P. M. (1988). Using direct and indirect measures to study perception without awareness. Perception and Psychophysics, 44(6), 563-575.

Ricker, T. J., \& Cowan, N. (2010). Loss of visual working memory within seconds: The combined use of refreshable and non-refreshable features. Journal of Experimental Psychology: Learning, Memory, and Cognition, 36(6), 1355.

Rieskamp, J., \& Otto, P. E. (2006). SSL: a theory of how people learn to select strategies. Journal of Experimental Psychology: General, 135(2), 207.

Romano, J. C., Howard, J. H., Jr., \& Howard, D. V. (2010). One-year retention of general and sequence-specific skills in a probabilistic, serial reaction time task. Memory, 18(4), 427-441. doi: 10.1080/09658211003742680

Scharlau, I. (2007). Perceptual latency priming: A measure of attentional facilitation. Psychological Research, 71(6), 678-686.

Schmidt, R. A., \& Bjork, R. A. (1992). New conceptualizations of practice: Common principles in three paradigms suggest new concepts for training. Psychological Science, 3(4), 207-218.

Schultz, W., Tremblay, L., \& Hollerman, J. R. (2003). Changes in behavior-related neuronal activity in the striatum during learning. Trends in Neurosciences, 26(6), 321-328.

Schweickert, R., \& Boruff, B. (1986). Short-term memory capacity: Magic number or magic spell? Journal of Experimental Psychology: Learning, Memory, and Cognition, 12(3), 419.

Shin, J. C., \& Ivry, R. B. (2002). Concurrent learning of temporal and spatial sequences. Journal of Experimental Psychology: Learning, Memory, and Cognition, 28(3), 445. 
Soderstrom, N. C., \& Bjork, R. A. (2015). Learning versus performance: An integrative review. Perspectives on Psychological Science, 10(2), 176-199.

Soetens, E., Melis, A., \& Notebaert, W. (2004). Sequence learning and sequential effects. Psychological Research, 69(1), 124-137.

Stadler, M. A. (1995). Role of attention in implicit learning. Journal of Experimental Psychology: Learning, Memory, and Cognition, 21(3), 674-685.

Staresina, B. P., \& Davachi, L. (2009). Mind the gap: binding experiences across space and time in the human hippocampus. Neuron, 63(2), 267-276.

Stark-Inbar, A., Raza, M., Taylor, J. A., \& Ivry, R. B. (2016). Individual differences in implicit motor learning: task specificity in sensorimotor adaptation and sequence learning. Journal of Neurophysiology, 117(1), 412-428.

Turk-Browne, N. B., Scholl, B. J., Johnson, M. K., \& Chun, M. M. (2010). Implicit perceptual anticipation triggered by statistical learning. Journal of Neuroscience, 30(33), 11177-11187. doi: 10.1523/JNEUROSCI.0858-10.2010

Ullman, M. T., Earle, S., Walenski, M., \& Janacsek, K. (2020). The neurocognition of developmental disorders of language. Annual Review of Psychology, 71, 389-417.

Vékony, T., Marossy, H., Must, A., Vécsei, L., Janacsek, K., \& Nemeth, D. (2019). Disentangling competence from performance in behavioral measures of learning: A lesson for cognitive neuroscience. bioRxiv, 726315.

West, G., Vadillo, M. A., Shanks, D. R., \& Hulme, C. (2017). The procedural learning deficit hypothesis of language learning disorders: we see some problems. Developmental Science.

Willingham, D. B., Greenberg, A. R., \& Thomas, R. C. (1997). Response-to-stimulus interval does not affect implicit motor sequence learning, but does affect performance. Memory and Cognition, 25(4), 534-542.

Wlotko, E. W., \& Federmeier, K. D. (2015). Time for prediction? The effect of presentation rate on predictive sentence comprehension during word-by-word reading. Cortex, 68, 20-32.

Zhang, W., \& Luck, S. J. (2009). Sudden death and gradual decay in visual working memory. Psychological Science, 20(4), 423-428. 


\title{
DISSOCIATION BETWEEN PERFORMANCE VS. COMPETENCE: A REVIEW ON THE ROLE OF TEMPORAL FACTORS THROUGH THE EXAMPLE OF PROCEDURAL LEARNING
}

\begin{abstract}
KISS, MARIANN - NÉMETH, DEZSÖ - JANACSEK, KAROLINA
It often occurs in our daily life that we perform weaker in a task in which we have previously shown good knowledge and understanding. In psychology, both theoretical and empirical evidence supports this phenomenon: that is, on certain occasions, our momentary performance does not accurately reflect our underlying knowledge (competence). The aim of our short, focused review paper is to draw attention to this performance vs. competence dissociation using the field of procedural learning as an example. It is important to note, however, that this phenomenon may occur for a wide range of cognitive functions (e.g., aspects of language performance, decision-making, perception), and therefore, our paper can stimulate research in these areas. In this paper, we review previous empirical findings that focused on the role of temporal factors in procedural learning as these factors can affect whether or not dissociation occurs in a certain case. Then, we briefly present the explanatory accounts of the role of the temporal factors in learning and in performance $v$ s. competence dissociation. Finally, our review discusses the implications of the presented findings both from a methodological and an applied perspective, highlighting that the dissociation between performance and competence can substantially alter the outcomes and our interpretations in various situations such as in education (e.g., skill learning, language learning) and when applying cognitive tests in clinical settings.
\end{abstract}

Keywords: performance vs. competence; implicit learning; probabilistic learning; response-to-stimulus interval (RSI)

A cikk a Creative Commons Attribution 4.0 International License (https://creativecommons. org/licenses/by/4.0) feltételei szerint publikált Open Access közlemény, melynek szellemében a cikk bármilyen médiumban szabadon felhasználható, megosztható és újraközölhetô, feltéve, hogy az eredeti szerzố és a közlés helye, illetve a CC License linkje és az esetlegesen végrehajtott módosítások feltüntetésre kerülnek. (SID_1) 